\title{
Research on Attitude Changing of Ideological and Political Education on College Students
}

\author{
Wei Wang \\ Student Affairs Office \\ North China University of Technology, Beijing 100144, \\ China \\ e-mail:ww@ncut.edu.cn
}

\author{
Xue Geng \\ College of Humanities and Law \\ North China University of Technology, \\ Beijing, China \\ e-mail:xgeng@ncut.edu.cn
}

\begin{abstract}
With the popularization of higher education, college students become an important part of university. As an important education method, the ideological and political education of college students will be the focus of the university ideological work. However, this motion plays an important role in the acceptance process of ideological and political education. Educator's emotion affects the understanding of students. At the same time, the emotion of student directly determines the cognition of ideological and political education of the recipient. Education content and emotion factors in education forms can strengthen or reduce the realization of acceptance of ideological and political education.
\end{abstract}

Keywords-Ideological and political educators; Education object attitude change, Attitude changing, Affection

\section{INTRODUCTION}

With the popularization of higher education, college students become an important part of university. Because some different factor's affects, college students face different kinds of problem. Ideological and political education is a purposeful applied ideological influence on people, to change people's thinking, and guide people to action in the social practice activities [1]. In these practice activities, the transformation of educational object attitude is a very important factor, when the education objects change their attitude, then they accept the education. Further, they change mind and conduct practice activities. Attitude belongs to advanced psychological activity of human beings, it is refers to the form in the course of social practice and individual, the ready state and psychological tendency towards the object specific cognition, evaluation, judgment and behavior [2] in relation to attitude change theory, the influence and the application deeply, widely used is the Hovland's cognitive dissonance theory model of persuasion and Festinger. At present, the research on the ideological and political education mainly consists of the relationship subject and object, single subject, the relationship of two subjects, the subject leading, etc. There exists little research on the educator's attitude affect on educatee.

According to the model of persuasion and cognitive dissonance theory, three basic elements to influence the attitude changing of the educated objects are education information, ideological and political educator and education situation in [2]. As the main body of the communication of information, some of the inherent characteristics of Ideological and political educator become an important factor affecting the changing of the object of ideological and political educator attitude. In this paper, we intends to explore the effect of ideological and political educator which change the education object attitude thought three aspects: the authority, credibility, personality charisma, in order to improve the effectiveness of ideological and political education $[4,10]$.

\section{THE IMPACT ON THE AUTHORITY OF IDEOLOGICAL AND POLITICAL EDUCATION ON COLLEGE STUDENTS}

As a source of Ideological and political education, education will directly affect the change of education object attitude. Psychology experiment repeatedly proved, reputation of the people can trigger more attitude change than people without reputation. This "ability" or "qualification" reflect the authority of education object, determines the extent to educators as knows the right information. Therefore, ideological and political education should establish the authority, to influence the change of education object attitude. According to the particularity of Ideological and political education, ideological and political educators must first have a proactive stance, it must have a solid knowledge of political theory. In addition, advancing with the times in the information society background, learn new things, to accept new things, constantly update our concepts and methods of education, but also the important content of Ideological and political education form authoritative.

\section{A. A positive attitude}

First, The Ideological and political education to educate the people, guide people, first he must of ideas, issues related to knowledge, understanding and recognition of the right, also is to have a positive attitude. Ideological and political education at present, positive attitude refers to adhere to Marx thought system, adhere to the socialist, communist beliefs, adhere to enhance people's awareness of the world, the ability to change the world. Ideological and political education through the theory of indoctrination, situational education as well as their own set an example by personally taking part, to guide the educated to abandon the backward ideas, establish a positive concept. If the educator's own position on the contrary and social development, this kind of negative, false ideas once taught the educated, if this idea just cognitive consistency of original and educated, then the firm more educated negative attitude; if this idea and the educated original cognitive conflict, educated by cognitive regulation may 
also change the original position, increase the new cognition.

\section{B. The Rich Experiences of Educator}

Evaluation of the educators, often based on their rich knowledge degree. Education vast knowledge can make the educated have respect and sense of convincing sense, so as to form a cohesive force and centripetal force, to make the educated actively to accept education and management. The education object if that students have expertise, is the expert or the field of the industry, will accept him, this goodwill will generalization to his education in the spread of information, and then accept education, the occurrence of a change in attitude. At the same time, the content of education of science has the logic of great strength and the realistic strength, able to persuade through reasoning, direct access to the heart. In addition, the education to have the rich knowledge, a wide range of interests and hobbies can and educationists have more resonance, change the attitude of the educated. Especially the university is the birthplace of broadcasting advanced science and culture, is the high-level personnel training base, has a broad knowledge of the ideological and political education, to exert a strong influence and persuasion in college students, change the attitude.

\section{The Advancing Attitude}

In the reform and opening up and the socialist market economic conditions, various new problems emerge in an endless stream, the new situation, ideological and political education work environment, tasks, content, channels and objects have changed a lot. Education only to keep pace with the times, admitted this change, accept this kind of change, to respond to this change, and the educated to resonate, accepted the educated. First of all, on the content of education, education to keep abreast of the latest dynamic, understand the pros and cons of the thought and speech, especially on negative thoughts and speech, can not be avoided, should raise them to guide the educated to be, conducive to get educated identity. Secondly, in teaching methods, to make corresponding changes and improvements, to change the ideological and political education mandatory, mandatory, change to adapt the market economy request participation, guidance; to change the previous simple "didactic", "explanation", turned to meet the populace mentality "induction type", "doubts"; to change the previous single, one-way form, into a new way of carrier, two-way interaction through various. [1] so as to make the greatest degree of Ideological and political education to get educated approval, change to the educated attitude.

\section{Attitude Effect of Trust to change College Studentes}

Credibility, also referred to as "honest", "intention justice", the credibility that the educated extent to educators as to tell the real information, trustworthy. Information dissemination trustworthy, it is conducive to the dissemination of information and acceptance. The credibility of the ideological and political education, the degree of trust or educated to the education intention, will affect the strength of the educated to accept the education, the possibility of a change in attitudes. The establishment of Ideological and political education of credibility depends on the following two points.

\section{(1) The Fair}

The fact proves, even if teachers have the authority, but if there is a loss of fairness and justice, the same can not be obtained by educators, change influence education attitude. The process of Ideological and political education, education fair performance make no exception in the treatment of the educated, respect, trust, educated, can make the educated on Ideological and political education and educators' favor and trust, strengthen the ideological and political education to accept the intention of education in accordance with the requirements, easy occurrence of attitude change. At the same time, the education embodies fairness, will influence education in influence character by environment for objective things attitude, develop scientific and impartial judgment consciousness and attitude change of consciousness.

\section{(2) The authenticity of Educational contents}

The content of Ideological and political education should have authenticity. The content of Ideological and political education reality depends both on the content itself, but also depends on certain education skills. The content itself authenticity requirement of Ideological and political education to transfer real, comprehensive, complete information, rather than intentionally cropped or shadowing. On this basis, the ideological and political education to master and use certain skills and methods, prove irrelevant to the educated guide attitude change and their own interests; to their comments attributed to the fact that, to make the educated are sure to explore the truth rather than personal gain; the abstract, direct information in education specifically, the emotional life of the material. In short, the ideological and political education should be good at the education content of aesthetic and visual, change the authenticity of the content of education to promote the influence character on environment by educated attitude.

(3) the real education content

The student's own needs and achievement goal.In social practice, because everyone's way of life and experience each are not identical, forming a unique personal needs and cognitive way of things, and to reflect on the learning motivation of cognition and demand varied also.Each person in need at the same time also is not the same, at the same level of intensity and reflect on the learning motivation strength also have very big difference. Students set different goals and formation of the target structure is different, also affects the students' learning motivation and learning behavior.

\section{INFLUENCE OF IDEOLOGICAL AND POLITICAL EDUCATION OF COLLEGE STUDENTES'S ATTITUDE}

The so-called personality is the unique mode of thinking, emotion and comprehensive constitute a person's behavior, psychological quality of [3] contains a person different from other people's stable and uniform, is the sum of all kinds of psychological characteristics of the individuals with a certain tendency, namely, a person's mental outlook. The so-called charm is its non power influence. Ideological and political education's personality charm is refers to the teacher in the student has prestige, reputation, has great influence and attraction.

It can fully mobilize the initiative, the educated study enthusiasm, accept them in the education process, adjust 
the cognitive balance, produce change of attitude, has the latent value of education more widely, more durable, more internal. The ideological and political education of personality charm mainly from the following two aspects affect the change of education object attitude.

\section{EXTERNAL TEMPERAMENT}

Temperament is a stable psychological characteristics, that is, we usually said the temper, disposition. [4] according to the theory of propagation, source appeal directly influence the acceptance. Education as a source in Ideological and political education process, its elegant demeanor, refined temperament, beautiful language, decent clothing, correct appearance, harmonious action expression, cheerful personality and attitude of humility, to enhance the education of external attraction and appeal. The attraction is big, easy to cause the goodwill of others and pleasant experience, will increase its influence. Easy to accept people for their love of people to provide information, and often believe firmly, will certainly can't help against criticism, he hates people provide information. External temperament elegant education will have a great influence on students' mind. All these are helpful to cultivate the educated mind and sentiment is conducive to the ideological and political education, is advantageous to transfer to guide the educated positive emotion, it will promote the transformation of education attitude. In psychology, the first effect also showed people, formed the first information impression will influence on the actions and evaluation later, the so-called "first impression". Therefore, the ideological and political education must pay attention to the cultivation of their external elegance, optimize the external impression, and pay attention to maintaining and improving in the daily education process.

\section{A. The real education content}

Ideological and political education content authenticity. The authenticity of the ideological and political education content is depends on the content itself, but also depends on the certain education skill. The authenticity of the content itself requirements of ideological and political educators to deliver real, comprehensive and complete information, rather than intentionally clipping or shadowing.On this basis, the ideological and political educators to master and apply some techniques and methods, to prove the educatees attitude change of lead has nothing to do with their own interests; Efforts will own comments attributed to the fact, make sure educatees to explore the truth but not the selfish; The abstract, direct the education of information in a specific, perceptual life of materials.[1], in short, the ideological and political educators must be good at to aesthetics education content and visualization, through education content the authenticity of the subtly transform of educatees attitude.

\section{B. The inherent character}

Ideological and political education in the student education management process, positive selfconsciousness shown towards work; have the courage to overcome difficulties, never yield in spite of reverses tenacity and tenacity; stick to the truth, the principle and the bull by the horns of the resolute and determined to solve difficult problems; in the cool, calm, patient, self-control in the student, go; evoked potential culture shown in the process of education students energetic and rich emotion and so on, will touch and influence education, to make it become the educated themselves will at the same time, about the role of other educational factors play, which determines the direction and strength of the educated ideological and political attitudes.

\section{Strengthen the education content of emotional expression}

The content of ideological and political education has a distinct political and class nature, easy to evolve into a mandatory preach, emotional conflict of educatees.As the ideological and political education workers, should give full play to the subjective initiative, necessary to reprocess the content of the education and emotional processing, makes every effort to make the content of ideological and political education has the time feeling, interesting and targeted, maximum activation of emotional factors, and through the rich and colorful teaching form pass this mood to educatees, to arouse the enthusiasm of educatees, promote the realization of education to accept.

\section{CONCLUSIONS}

In terms of China's national conditions, ideological and political education plays very important role in school education. Our ideological and political education faces many new challenges. Attitude changing of ideological and political educator has the very large influence on the education result. In this paper, according to ideological and political educator, education information, education target and education environment, we will study the influence of the change from the ideological and political education object of educators, in order to improve the effectiveness of the ideological and political education.

\section{ACKNOWLEDGMENT}

This research was financially supported by the Excellent Young Teachers Program of North China University of Technology.

\section{REFERENCES}

[1] Yang ZhiYing, Wang XiYong. Ideological and political education psychology. Beijing: the capital normal university press, 1999.

[2] Wu Lei Ming. Attitude change in the ideological and political education theories in the research on the application of. The ideological and political education research, 2010, 9.

[3] Yang ChangQing. Ideological and political educators: influence of educatees attitude change key factors. Ideological and political education research, 2007, 6 (total 88 phase).

[4] Dan Peng . Common psychology. Beijing: Beijing normal university press, 2001.

[5] W. Strunk Jr., E.B. White, The Elements of Style, third ed., Macmillan, New York, 1979.

[6] G.R. Mettam, L.B. Adams, How to prepare an electronic version of your article, in: B.S. Jones, R.Z. Smith (Eds.), Introduction to the Electronic Age, E-Publishing Inc., New York, 1999, pp. 281-304.

[7] R.J. Ong, J.T. Dawley and P.G. Clem: submitted to Journal of Materials Research (2003) 
[8] P.G. Clem, M. Rodriguez, J.A. Voigt and C.S. Ashley, U.S. Patent 6,231,666. (2001) Information on http://www.weld.labs.gov.cn

[9] Zhou Yifeng. Study on the ideological and political education in social transition, vol.12(2), pp.34-39,2013.

[10] J. Clerk Maxwell, A Treatise on Electricity and Magnetism, 3rd ed., vol. 2. Oxford: Clarendon, 1892, pp.68-73.

[11] I. S. Jacobs and C. P. Bean, "Fine particles, thin films and exchange anisotropy," in Magnetism, vol. III, G. T. Rado and H. Suhl, Eds. New York: Academic, 1963, pp. 271-350.

[12] K. Elissa, "Title of paper if known," unpublished.
[13] R. Nicole, "Title of paper with only first word capitalized," J. Name Stand. Abbrev., in press.

[14] Y. Yorozu, M. Hirano, K. Oka, and Y. Tagawa, "Electron spectroscopy studies on magneto-optical media and plastic substrate interface," IEEE Transl. J. Magn. Japan, vol. 2, pp. 740741, August 1987 [Digests 9th Annual Conf. Magnetics Japan, p. 301, 1982].

[15] M. Young, The Technical Writer's Handbook. Mill Valley, CA: University Science, 1989. 